\title{
Anisomycin induces apoptosis of glucocorticoid resistant acute lymphoblastic leukemia CEM-C1 cells via activation of mitogen-activated protein kinases p38 and JNK
}

\author{
Y. LIU, J. GE, Q. LI*, L. GU, X. GUO, Z. G. MA, Y. P. ZHU \\ Department of Pediatric Hematology and Immunology, West China Second University Hospital, Sichuan University. 610041 Chengdu, China \\ *Correspondence: lqcm2000@yahoo.com.cn
}

Received May 31, 2012 / Accepted August 6, 2012

\begin{abstract}
Glucocorticoids (GCs) resistance is frequently encountered in children with acute lymphoblastic leukemia (ALL), especially T-ALL, which usually results in failure of treatment. To find new agent to overcome GC resistance of ALL is an urgent problem. Here we investigated potential effect of anisomycin on GC-resistant T-ALL CEM-C1 cells and explored involved molecular mechanisms. Dramatic growth inhibition and apoptosis in GC-resistant CEM-C1 cells and GC-sensitive CEM-C7 cells induced by anisomycin were observed, which presented in a concentration- and time-dependent manner. Correspondingly, anisomycin induced cleaved caspase-3 and up-regulation of pro-apoptotic proteins (BimEL and Bad), meanwhile down-regulation of anti-apoptotic proteins (Mcl-1 and Bcl-2), both in a dose- and time-dependent manner in GC resistant CEM-C1 cells. Anisomycin also induced cell cycle arrest at G0/G1 phase in CEM-C1 cells through increasing expressions of p21 and p27, and attenuating the expression of cyclinA. The rapid up-regulation of phosphorylated mitogen-activated protein kinases (MAPKs) p38 and Jun N-terminal kinase (JNK) were observed after CEM-C1 cells were incubated with anisomycin. The activation of p38-MAPK and JNK could be blocked by respective inhibitors (SB203580 for p38-MAPK and SP600125 for JNK) accompanied with the inhibition of apoptosis and changes of apoptosis-associated proteins in CEM-C1 cells. These results suggested that anisomycin induced apoptosis of CEM-C1 cells via activation of p38-MAPK and JNK, and might be an attractive new agent for treatment of GC-resistant ALL.
\end{abstract}

Key words: anisomycin, acute lymphoblastic leukemia (ALL), glucocorticoid resistance, apoptosis, p38-Mitogen-Activated Protein Kinase (p38-MAPK), Jun N-terminal kinase (JNK)

Glucocorticoids (GCs) have been used to treat hematological malignancies for decades, and constituted a central role in the treatment of acute lymphoblastic leukemia (ALL)[1]. The sensitivity of leukemic cells to GCs is strongly relevant to therapeutic efficacy and prognosis in childhood ALL [2], and the resistance to GCs is the most important reason for treatment failure [3]. Clinically, GC resistance occurs in 10\% 30\% of childhood primary ALL, especially in T-ALL, and up to $70 \%$ in relapsed ALL. Therefore, aiming at GC resistance in ALL, to explore new therapeutic agents is an urgent clinical program. Previous studies have demonstrated that GCs induce apoptosis in lymphoid cells through activation of glucocorticoid receptor (GR) which was phosphorylated at serine 211 mediated by p38-MAPK [4], and the GC sensitivity in lymphoid cells can be enhanced by activation of p38-MAPK [5]. Hence, we supposed that the p38-MAPK agonists maybe possess the potential of inducing apoptosis in GC-resistant ALL cells through activating p38-MAPK. Anisomycin, known as a protein synthesis inhibitor, is also an agonist of p38-MAPK[6], and has been used to induce apoptosis in some solid tumors[7-13]. Here, we reported for the first time that anisomycin induced dramatic apoptosis of GC-resistant human T-ALL CEM-C1 cells via activation of p38-MAPK and JNK.

\section{Materials and methods}

Cell lines and reagents. Human T-ALL cell lines of GCsensitive CEM-C7-14 and GC-resistant CEM-C1-15 were kindly gifted by E.B.Thompson (University of Texas Medical Branch, Galveston, TX). We will refer to these cell lines as CEM-C7 and CEM-C1 in the following text. Dexamethasone (DEX, D1756), anisomycin (A9789), SB203580 (S8307) and 
SP600125 (S5567) were all obtained from Sigma Aldrich and dissolved in ethanol or dimethyl sulfoxide (DMSO). MTT and Propidium iodide (PI) were purchased from Sigma. Annexin V-PI Kit was purchased from Keygen (Nanjing, China). Antibodies for p38, phosphorylated p38(p-p38), Jun $\mathrm{N}$-terminal kinase 1 (JNK1), phosphorylated JNK (p-JNK), Bad, Bim, Bax, Bcl-2, Mcl-1, caspase-3 (cleaved at Asp175), cyclin A, cyclinD1 and the secondary antibodies of horseradish peroxidase (HRP)-conjugated sheep anti-rabbit antibody and HRP-conjugated sheep anti-mouse antibody were all obtained from Santa Cruz Biotech (USA). Antibodies for p21 and p27 were purchased from BD Bioscience (San Jose, CA, USA) and Cell Signaling Technology (Beverly, MA, USA), respectively. Anti-GAPDH antibody was obtained from Kangcheng BioTech (Shanghai, China). ECL plus came from Amersham Biosciences(Inc., Piscataway, NJ).

Cell culture. Cells were maintained in RPMI-1640 medium supplemented with $10 \%$ fetal bovine serum, $2 \mathrm{mM}$ glutamine, $100 \mathrm{U} / \mathrm{ml}$ penicillin $/$ streptomycin and cultured at $37^{\circ} \mathrm{C}$ in a $5 \%$ $\mathrm{CO} 2$ humidified atmosphere.

Detection of cell growth inhibition by MTT test. Cells in logarithmic growth phase were seeded in 96-well plate $\left(2 \times 10^{4}\right.$ cells per well) with different final concentrations of anisomycin $(0.1 \mu \mathrm{mol} / \mathrm{L}, 1 \mu \mathrm{mol} / \mathrm{L}$ and $10 \mu \mathrm{mol} / \mathrm{L})$ and incubated for various times. Then, $20 \mu \mathrm{L}$ MTT solution $(5 \mathrm{mg} / \mathrm{mL})$ was added to each well and cells were incubated for additional $4 \mathrm{~h}$ at $37^{\circ} \mathrm{C}$ and centrifuged at $1000 \mathrm{rpm}$ for $10 \mathrm{~min}$. The supernatant was gently removed from cell pellet and $150 \mu$ of DMSO (Sigma, USA) was added to each well. The plate was gently shaken for 10 minutes and the absorbance at $570 \mathrm{~nm}$ was measured with an ELISA reader. Three separate experiments were conducted and each was performed in triplicate. The inhibition ratio of ALL cells was calculated based on the formula: Inhibition rate $(\%)=(1$-absorbance of the experimental group/absorbance of the control group) $\times 100 \%$.

Morphology observation of apoptosis by Wright's Giemsa staining. Cells in logarithmic growth phase were seeded in 24 -well plate with the density of $2 \times 10^{5} / \mathrm{ml}$ and incubated with $1 \mu \mathrm{mol} / \mathrm{L}$ anisomycin for $12 \mathrm{~h}$. Then, cells were collected, washed, re-suspended and spin down (800rpm, 3min) onto glass slides. After staining with Wright's Giemsa, the morphology of cells was observed under light microscopy.

Measurement of apoptosis and cell cycle by flow cytometry. Cells in logarithmic growth phase were seeded in 6-well plate with the density of $2 \times 10^{5} / \mathrm{ml}$ and incubated with different concentrations of anisomycin $(0.1 \mu \mathrm{mol} / \mathrm{L}, 1 \mu \mathrm{mol} / \mathrm{L}$ and $10 \mu \mathrm{mol} / \mathrm{L}$ ) for $6 \mathrm{~h}$ (for cell cycle analysis) or $12 \mathrm{~h}$ (for detection of apoptosis), respectively. The cells were collected, washed and re-suspended at $1 \times 10^{6}$ cells $/ \mathrm{ml}$ in $500 \mu \mathrm{l}$ binding buffer containing $5 \mu$ of Annexin V-FITC stock solution and $10 \mu \mathrm{l}$ of PI. After incubated for $10 \mathrm{~min}$ at room temperature in the dark, the apoptosis of cells was detected by flow cytometry. For cell cycle analysis, cells were fixed overnight in $70 \%$ ethanol at $4^{\circ} \mathrm{C}$, washed, stained with $5 \mu \mathrm{g} / \mathrm{ml} \mathrm{PI}$ and analyzed by flow cytometry. For investigating the effect of inhibitors on apoptosis (section 3.4), cells were preincubated with inhibitors of $\mathrm{p} 38$-MAPK and JNK respectively for $1 \mathrm{~h}$, followed by incubation with anisomycin for $24 \mathrm{~h}$, then the apoptosis of cells was detected as described above.

Western blot analysis of proteins. CEM-C1 cells in logarithmic growth phase were treated with DEX or anisomycin for the indicated time points. Then, cells were harvested, washed and lysed in Laemmli sample buffer (Bio-Rad, Hercules, CA, USA). Protein concentration was determined by Coomassie brilliant blue. Samples were boiled for $5 \mathrm{~min}$ at $100^{\circ} \mathrm{C}$ and insoluble material was removed by centrifugation. $25 \mu \mathrm{g}$ $40 \mu$ g proteins were separated on $12 \%$ SDS-polyacrylamide gel electrophoresis (SDS-PAGE) and transferred onto PVDF membranes $(0.2 \mu \mathrm{m}$, Mllipore, São Paulo, SP, Brazil). The membranes were incubated with primary antibody at $4^{\circ} \mathrm{C}$ overnight. After washing 3 times with TBST, the membranes were incubated for $2 \mathrm{~h}$ at room temperature with secondary HRPconjugated sheep anti-rabbit antibody or HRP-conjugated sheep anti-mouse antibody diluted 1:3000 in TBST with 5\% non-fat milk. Proteins were visualized using the ECL detection system (Amersham Biosciences, Oxford, United Kingdom). For investigating the effect of inhibitors (section 3.4), cells were preincubated with inhibitors of p38-MAPK and JNK respectively for $1 \mathrm{~h}$ prior to anisomycin treatment, and at the indicated time points, proteins were extracted and detected by western blotting as described above. The level of the GAPDH was used as a control of the amount of protein loaded into each lane and the quantification of the density of the bands on the blots was performed using Image J software. All experiments were carried out independently at least 3 times.

Statistical analysis. All experiments were performed in triplicate, and data were expressed as mean values \pm SD. All statistical analyses were carried out with SPSS 17.0 software and multiple groups were compared with One-way ANOVA. Values were considered statistically significant with $p$-value $<0.05$.

\section{Results}

Anisomycin induces growth inhibition on both GC-resistant CEM-C1 cells and GC-sensitive CEM-C7 cells. Both CEM-C1 and CEM-C7 cells belong to T-ALL cell lines, but they have absolutely opposite sensitivity to GCs. The previous studies by Thompsom et al. [14] and our group [15] have confirmed that CEM-C7 cells were very sensitive to DEX, while CEM-C1 cells were highly resistant to DEX. To test whether anisomycin induces growth inhibition on GC-resistant CEM-C1 cells, we first treated CEM-C1 cells with different concentrations of anisomycin for various times and used CEM-C7 cells as a control. As shown in Fig.1, just $0.1 \mu \mathrm{mol} / \mathrm{L}$ anisomycin treated for $24 \mathrm{~h}$ had a remarkable growth inhibition on CEM-C1 and CEM-C7 cells, and the inhibition rates were $46.68 \% \pm 5.28 \%$ and $49.00 \% \pm 7.57 \%$, respectively. The high concentration of anisomycin $(10 \mu \mathrm{mol} / \mathrm{L})$ manifested strong growth inhibition on both cells after only $6 \mathrm{~h}$ incubation, and the inhibition rates were nearly same as that of $24 \mathrm{~h}$ incubation with $0.1 \mu \mathrm{mol} / \mathrm{L}$ 


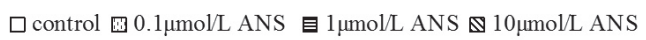

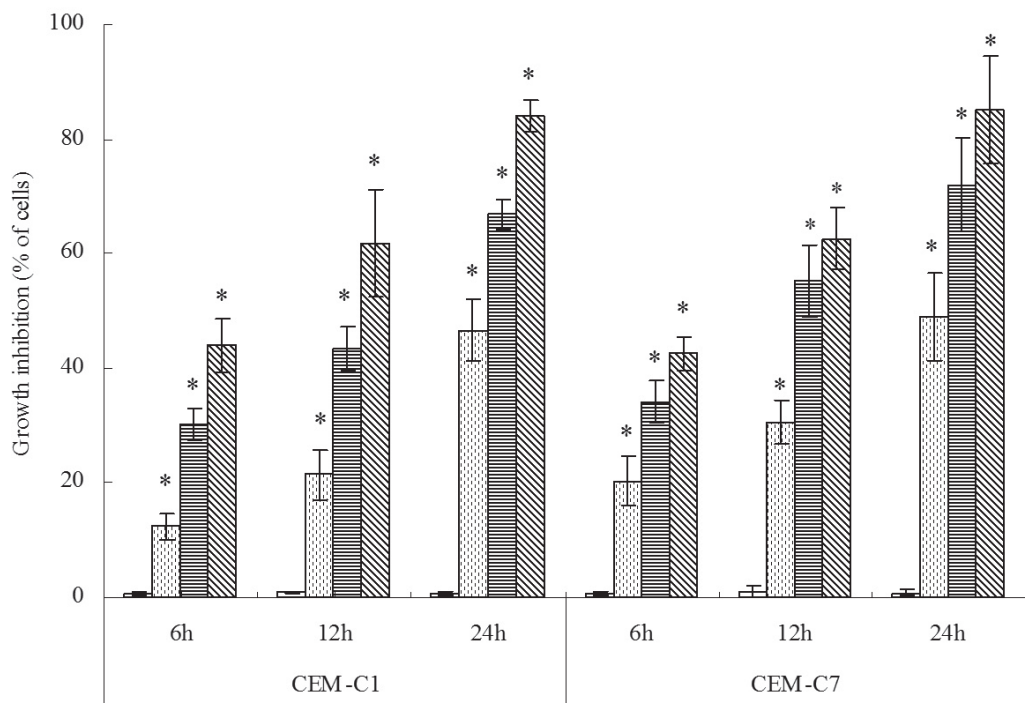

Figure 1. Growth inhibition of GC-resistant CEM-C1 cells and GC-sensitive CEM-C7 cells induced by anisomycin. Both CEM-C1 and CEM-C7 cells were incubated with different concentrations of anisomycin (ANS, $0.1 \mu \mathrm{mol} / \mathrm{L}, 1 \mu \mathrm{mol} / \mathrm{L}$ and $10 \mu \mathrm{mol} / \mathrm{L}$ ) for $6 \mathrm{~h}, 12 \mathrm{~h}, 24 \mathrm{~h}$, respectively. The inhibition rate of cells was evaluated by MTT assay. Values represent the mean \pm S.D. of three independent experiments. ${ }^{*} p<0.05$ as compared with control group.

anisomycin. These results indicated that anisomycin had a powerful growth inhibition on both GC-resistant CEM-C1 cells and GC-sensitive CEM-C7 cells, and the effect presented in a concentration- and time-dependent manner.

Anisomycin induces apoptosis in both GC-resistant CEM-C1 cells and GC-sensitive CEM-C7 cells. As shown in Fig.2A, after incubation with $0.1 \mu \mathrm{mol} / \mathrm{L}$ anisomycin for $12 \mathrm{~h}$, CEM-C1 cells displayed apoptotic bodies occasionally, while CEM-C1 cells showed typical feature of apoptosis, including cell shrinkage, apoptotic bodies and chromatin condensation to nuclear membrane after incubation with $1 \mu \mathrm{mol} / \mathrm{L}$ anisomycin for $12 \mathrm{~h}$, and when CEM-C1 cells were incubated with $10 \mu \mathrm{mol} / \mathrm{L}$ anisomycin for $12 \mathrm{~h}$, nuclear fragmentation and cell debris appeared clearly besides apoptotic bodies. CEM-C7 cells also had apoptosis in a concentration-dependent manner and mainly manifested as apoptotic bodies formation, cell shrinkage and cell debris. Meanwhile, we treated CEM-C1 and CEM-C7 cells with different concentrations of anisomycin for $12 \mathrm{~h}$ to detect apoptosis by Annexin V-FITC/PI staining and flow cytometry. As shown in Fig.2B, The apoptosis induced by anisomycin presented in a concentration-dependent manner in both CEM-C1 and CEM-C7 cells. These data indicated that anisomycin could induce apoptosis not only in GC-sensitive CEM-C7 cells but also in GC-resistant CEM-C1 cells.

To further test pathogenesis of anisomycin-induced apoptosis in CEM-C1 cells, we selectively detected expression changes of Bcl-2 family proteins which were thought to be associated with GC resistance [16-18]. As shown in Fig.3A, the expressions of pro-apoptotic proteins BimEL and Bad in CEM-C1 cells were up-regulated while anti-apoptotic proteins Bcl-2 and Mcl-1 were down-regulated, both presenting in a concentration-dependent manner. Cleaved caspase- 3 also increased. In addition, different changes of Bcl-2 family proteins were also observed when CEM-C1 cells were incubated with $1 \mu \mathrm{mol} / \mathrm{L}$ anisomycin for different times. As shown in Fig.3B the expression of pro-apoptotic protein BimEL was increased as early as $30 \mathrm{~min}$ after cells were incubated with anisomycin, and continued high expression up to $48 \mathrm{~h}$. The expression of Bad began increasing $1 \mathrm{~h}$ after CEM-C1 cells were incubated with $1 \mu \mathrm{mol} / \mathrm{L}$ anisomycin, and kept high expression until $24 \mathrm{~h}$ and then decreased. There was no obvious change in Bax. In contrast to pro-apoptotic proteins, the expression of anti-apoptotic proteins Mcl-1 markedly decreased 30min after CEM-C1 cells were incubated with $1 \mu \mathrm{mol} / \mathrm{L}$ anisomycin and kept low expression until $48 \mathrm{~h}$, meanwhile $\mathrm{Bcl}-2$ began decreasing obviously at $6 \mathrm{~h}$, kept continuous decreasing and finally disappeared at $48 \mathrm{~h}$. Activation of caspase-3 (cleaved into $\mathrm{p} 17$ and $\mathrm{p} 12$ fragments) appeared $3 \mathrm{~h}$ after CEM-C1 cells were treated with $1 \mu \mathrm{mol} / \mathrm{L}$ anisomycin, and kept significantly increased till $48 \mathrm{~h}$. These results suggested that anisomycin induced apoptosis in CEM-C1 cells through mitochondrial apoptotic pathway.

Anisomycin induces cell cycle arrest in both GC-resistant CEM-C1 cells and GC-sensitive CEM-C7 cells. Cell cycle regulation is an important process in cells undergoing apoptosis. To test whether anisomycin induced cell cycle arrest in GC-resistant CEM-C1 cells, different concentrations of anisomycin $(0.1 \mu \mathrm{mol} / \mathrm{L}, 1 \mu \mathrm{mol} / \mathrm{L}$ and $10 \mu \mathrm{mol} / \mathrm{L})$ were used to treat CEM-C1 and CEM-C7 cells (as a control) for $6 \mathrm{~h}$ and cell cycle arrest was detected by PI staining and flow cytometry. As shown in Fig.4, anisomycin induced a significant increased proportion of G0/G1 phase, and a simultaneously decreased 
A
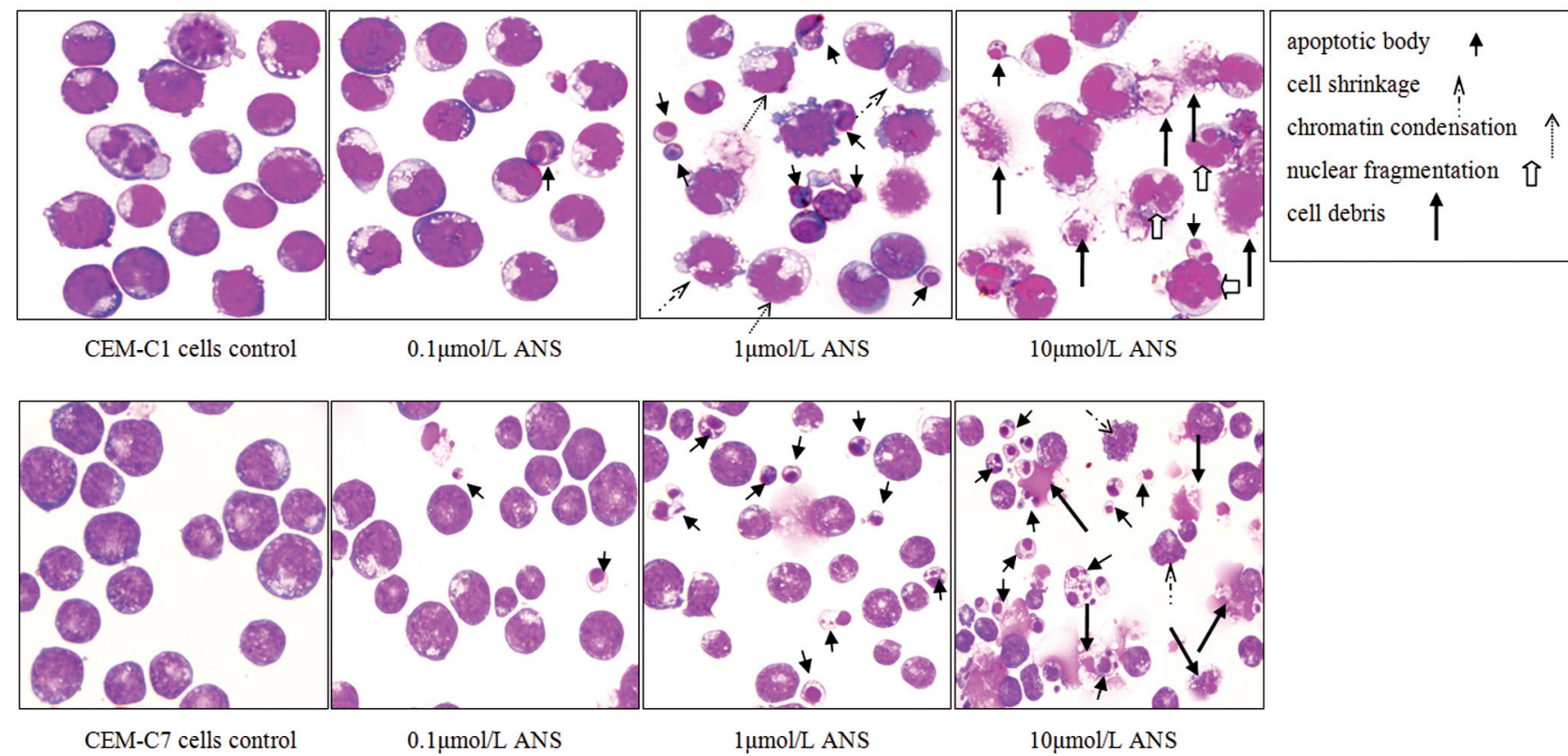

B

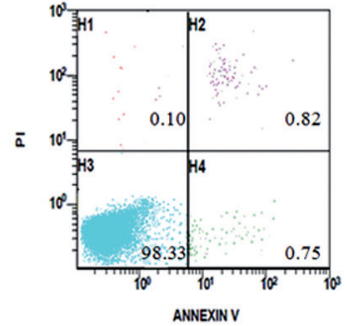

CEM-C1 cells control

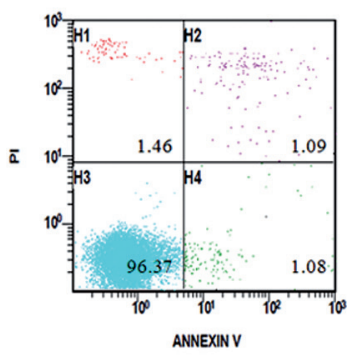

CEM-C7 cells control

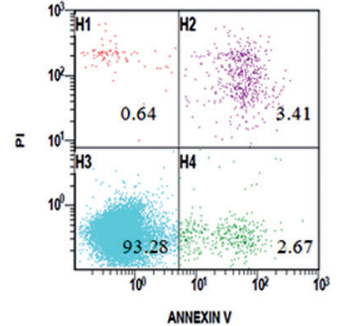

$0.1 \mu \mathrm{mol} / \mathrm{L}$ ANS

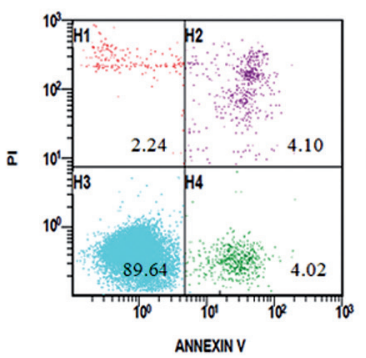

$0.1 \mu \mathrm{mol} / \mathrm{L}$ ANS

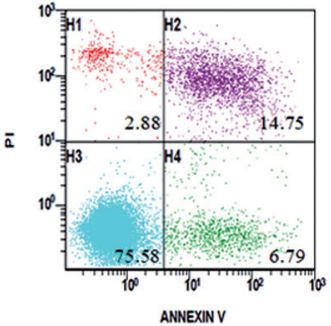

$1 \mu \mathrm{mol} / \mathrm{L}$ ANS

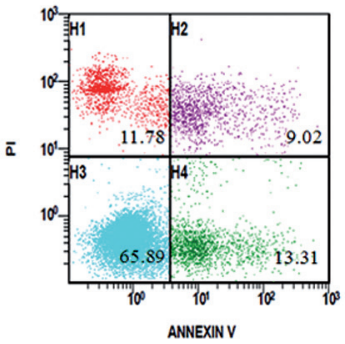

$1 \mu \mathrm{mol} / \mathrm{L}$ ANS

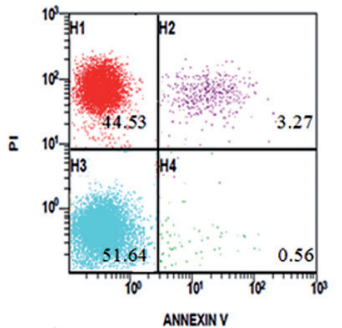

$10 \mu \mathrm{mol} / \mathrm{L}$ ANS

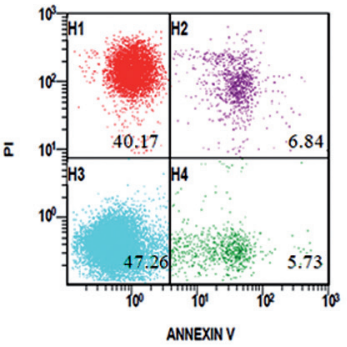

$10 \mu \mathrm{mol} / \mathrm{L}$ ANS

Figure 2. Apoptosis of GC-resistant CEM-C1 cells and GC-sensitive CEM-C7 cells induced by anisomycin. CEM-C1 and CEM-C7 cells were incubated with different concentrations of ANS (anisomycin, $0.1 \mu \mathrm{mol} / \mathrm{L}, 1 \mu \mathrm{mol} / \mathrm{L}$ and $10 \mu \mathrm{mol} / \mathrm{L}$ ) for $12 \mathrm{~h}$, respectively. (A) The morphological changes of cells were examined by Wright's Giemsa staining and then observed under microscope at a magnification of $10 \times 40$. (B) The percentage of apoptotic cells was determined by Annexin V-FITC/PI staining and flow cytometry. Percentages of each gated fraction (\%) have been marked on the pictures.

proportion of S and G2/M phase in both cell lines suggesting that anisomycin arrested both GC-sensitive CEM-C7 cells and GC-resistant CEM-C1 cells at G0/G1 phase in a concentration -dependent manner.
To explore the molecular mechanisms of anisomycin-induced cell cycle arrest, we investigated the expressions of cell cycle regulatory proteins in CEM-C1 cells. As shown in Fig.5A, anisomycin induced up-regulation of cyclinD1, p21 and p27 


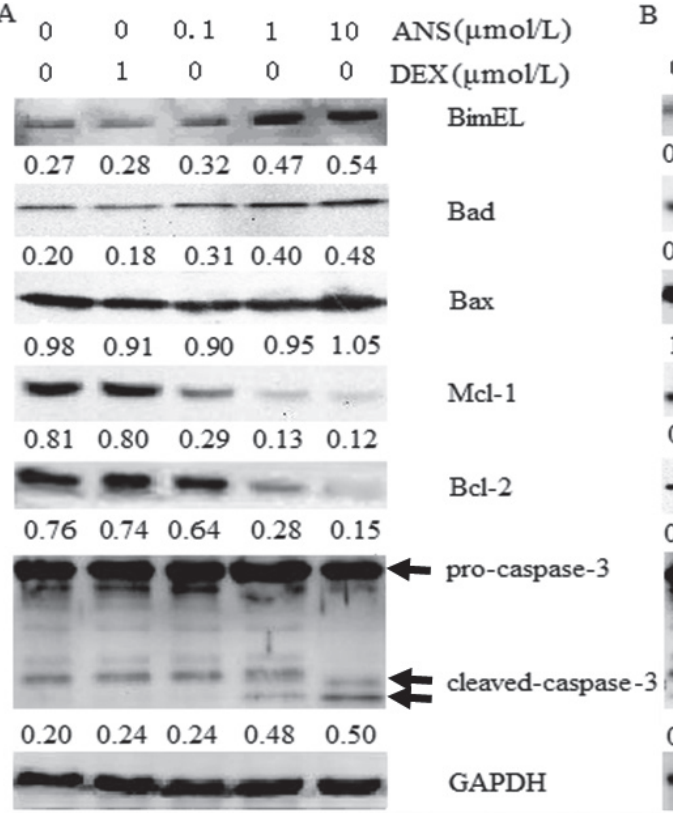

B
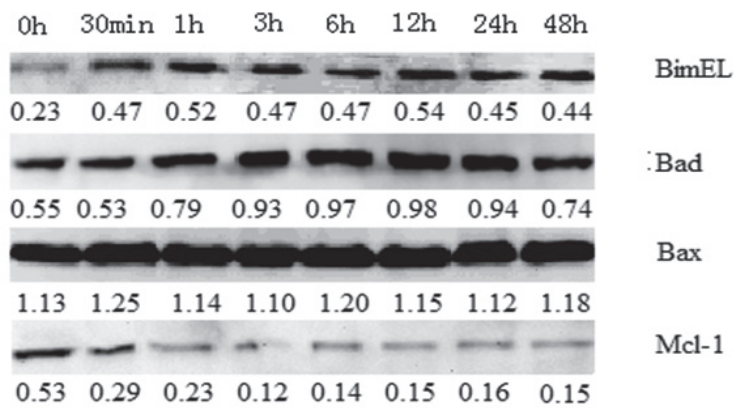

Bcl-2

$\begin{array}{llllllll}0.30 & 0.29 & 0.32 & 0.32 & 0.19 & 0.15 & 0.14 & 0.04\end{array}$

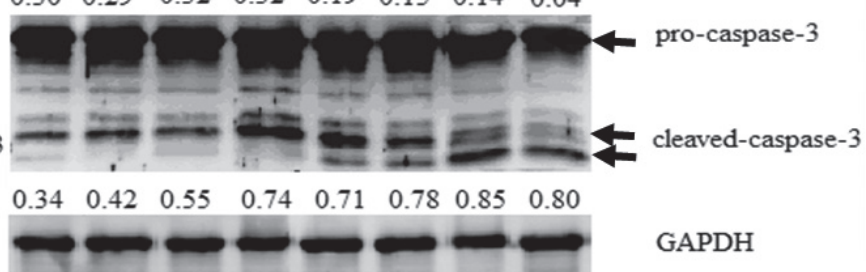

Figure 3. Expressions of Bcl-2 family proteins and caspase-3 in GC-resistant CEM-C1 cells induced by anisomycin. CEM-C1 cells were incubated with (A) the indicated concentrations of DEX or ANS (anisomycin) for $6 \mathrm{~h}$ or (B) $1 \mu \mathrm{mol} / \mathrm{L}$ anisomycin for the indicated times, and then cells were collected, lysed and extracts were subjected to western blot analysis. BimEL, Bad, Bax, Mcl-1, Bcl-2 and caspase-3 were detected by using specific antibodies against these proteins. The data of densitometry which standardized by GAPDH are presented below the band.

while down-regulation of cyclinA in a concentration-dependent manner. When CEM-C1 cells were treated with $1 \mu \mathrm{mol} / \mathrm{L}$ anisomycin for different times (Fig.5B), the expression of cyclin A decreased obviously after $6 \mathrm{~h}$ and kept decline up to $48 \mathrm{~h}$, while the expression of cyclin D1 increased after $30 \mathrm{~min}$ and kept elevated up to $48 \mathrm{~h}$. P27 and p21 increased gradually after 30min (p27) and $3 \mathrm{~h}$ (p21) respectively, continued increasing up to $12 \mathrm{~h}(\mathrm{p} 27)$ and $24 \mathrm{~h}(\mathrm{p} 21)$, and then both decreased. These results indicated that anisomycin arrested CEM-C1 cells at G0/G1 phase through up-regulating p27 and p21 and down-regulating cyclin A in a concentration- and time-dependent manner.

Anisomycin induces p38-MAPK and JNK activation in GC-resistant CEM-C1 cells. As shown in Fig.6, the expression of phosphorylated p38-MAPK (p-p38-MAPK) in CEM-C1 cells treated with anisomycin began increasing after $30 \mathrm{~min}$ incubation, arrived at peak after $1 \mathrm{~h}$, and then decreased after $3 \mathrm{~h}$, presenting in a time-dependent manner. Unlike p-p38-MAPK, phosphorylated JNK (p-JNK) was rapidly activated, arrived at peak just after $30 \mathrm{~min}$ and almost disappeared after $3 \mathrm{~h}$. To test whether the two kinases have a specific role in anisomycin-induced apoptosis, the respective inhibitors (SB203580 for p38-MAPK, SP600125 for JNK) were used to treat CEM-C1 cells for $1 \mathrm{~h}$ prior to anisomycin treatment. As shown in Fig.7, the activation of p38-MAPK and JNK in CEM-C1 cells induced by anisomycin could be blocked by respective specific inhibitors, which was accompanied with changes of cell apoptosis and expressions

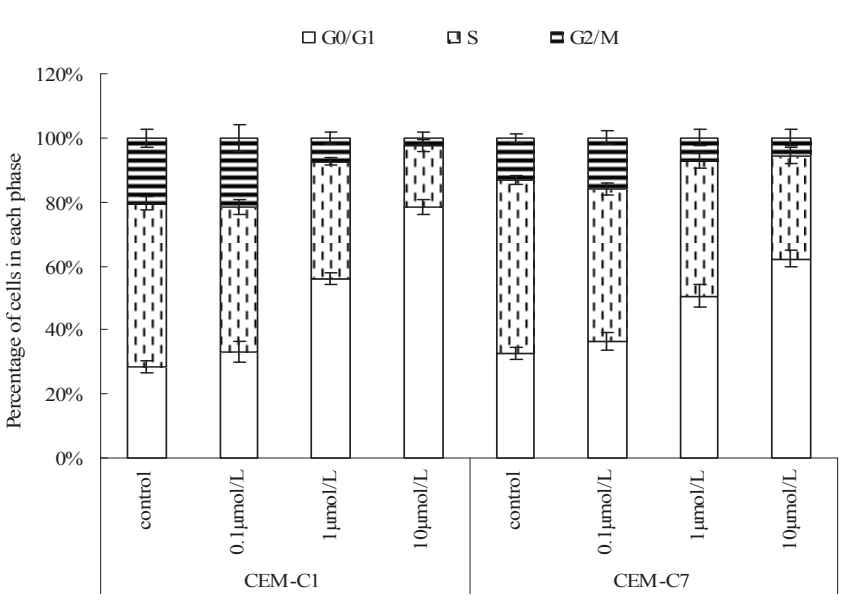

Figure 4. Cell cycle arrest of GC-resistant CEM-C1 cells and GC-sensitive CEM-C7 cells induced by anisomycin. CEM-C1 and CEM-C7 cells were incubated with different concentrations of anisomycin $(0.1 \mu \mathrm{mol} / \mathrm{L}$, $1 \mu \mathrm{mol} / \mathrm{L}$ and $10 \mu \mathrm{mol} / \mathrm{L}$ ) for $6 \mathrm{~h}$, respectively. Then the percentage of cells at each stage of the cell cycle was detected by PI staining and flow cytometry. Values represent the mean \pm S.D. of three independent experiments.

of Bcl-2, Mcl-1 and BimEL, indicating anisomycin-induced apoptosis in CEM-C1 cells might be through p38-MAPK and JNK signal pathways. 


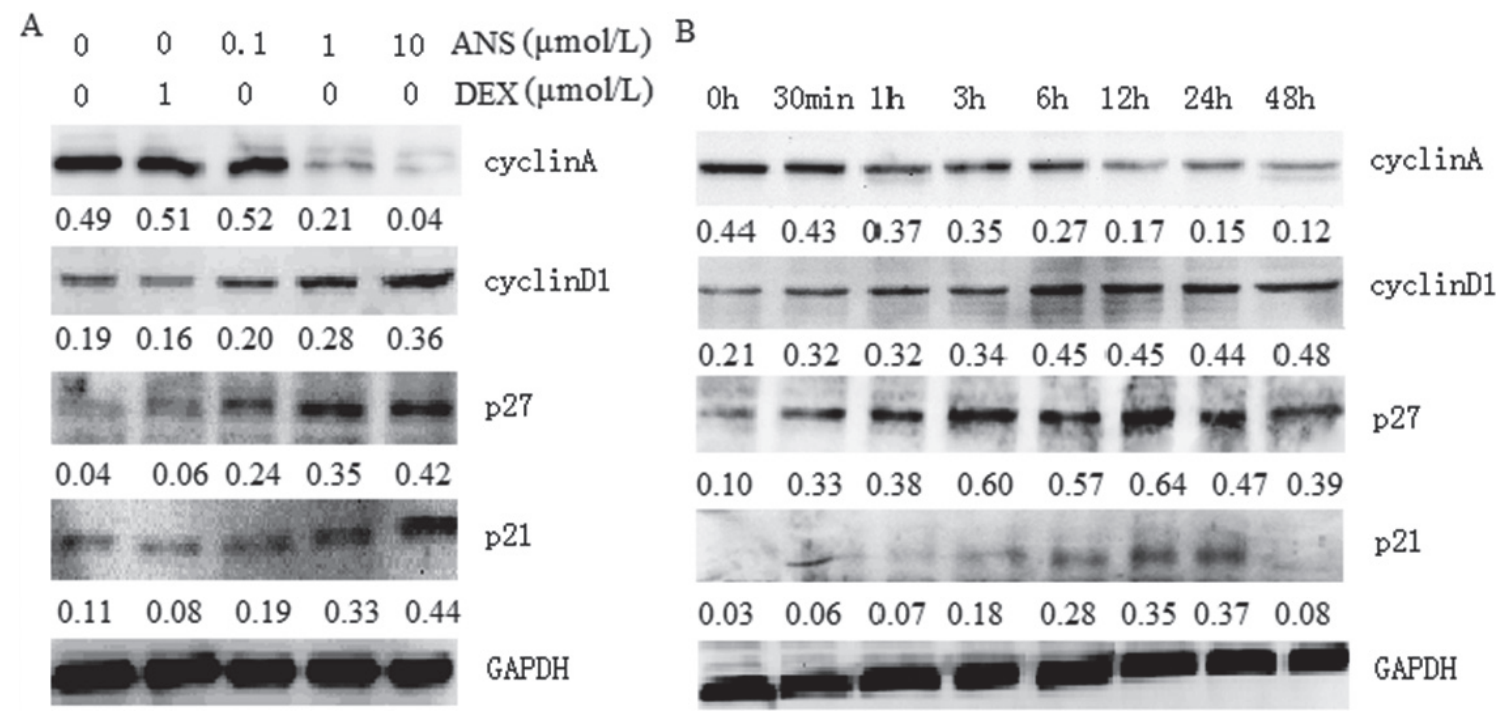

Figure 5. Expressions of cell cycle regulatory proteins in GC-resistant CEM-C1 cells induced by anisomycin. CEM-C1 cells were incubated with (A) the indicated concentrations of DEX or ANS (anisomycin) for $6 \mathrm{~h}$ or $(\mathrm{B}) 1 \mu \mathrm{mol} / \mathrm{L}$ anisomycin for the indicated times, and then cells were collected, lysed and extracts were subjected to western blot analysis. Cyclin A, cyclinD1, p27 and p21 were detected by using specific antibodies against these proteins. The data of densitometry which standardized by GAPDH are presented below the band.

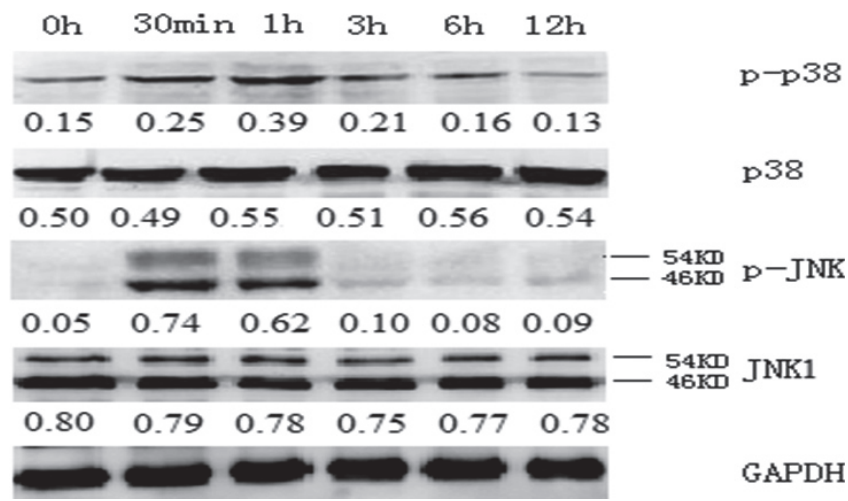

Figure 6. Expressions of phosphorylated p38 and JNK in GC-resistant CEM-C1 cells induced by anisomycin. CEM-C1 cells were incubated with $1 \mu \mathrm{mol} / \mathrm{L}$ anisomycin for indicated times, and then cells were collected, lysed and extracts were subjected to western blot analysis. P-p38 (Thr-180/Tyr-182), p38, p-JNK (Thr-183/Tyr-185), and JNK1 were detected by using specific antibodies against these proteins. The data of densitometry which standardized by GAPDH are presented below the band.

\section{Discussion}

Anisomycin induces apoptosis of CEM-C1 cells through regulating the expression of pro- and anti-apoptotic proteins. The apoptosis of most tumor cells induced by chemotherapeutic drugs proceeds through the mitochondria pathway, and the Bcl2 family proteins play a pivotal role. The pro-apoptotic Bim is of important role in GC resistance of ALL. Previous studies have demonstrated that the absence of Bim up-regulation after treated with DEX appears to be one of the most important mechanisms of GC resistance in ALL cells [15,18-19]. Bim mediates apoptosis by binding to anti-apoptotic members of the Bcl-2 family (e.g., Bcl-2, Mcl-1 and Bcl-xL) [20] or by activating pro-apoptotic members Bax and Bak[21]. Bad, another important pro-apoptotic factor, is mainly distributed in cytoplasm and promotes cells to apoptosis by forming hetero-dimer with anti-apoptotic $\mathrm{Bcl}-2$ and $\mathrm{Bcl}-\mathrm{XL}[21]$. Otherwise, two anti-apoptotic proteins in Bcl-2 family are associated with GC resistance of ALL. Mcl-1, usually over-expressed in a variety of human cancers including GC-resistant MLL rearranged infant ALL[16,22], promotes cells survive by forming hetero-dimer with pro-apoptotic proteins (such as Bax, Bak or Bim) to prevent the releasing of cytochrome c[21]. Bcl-2 is also over-expressed in many kinds of cancer cells and tightly related to drug resistance including GC resistance $[23,24]$. The increase of $\mathrm{Bcl}-2 / \mathrm{Bax}$ ratio is related to chemotherapeutic drug resistance in B cell chronic lymphocytic leukemia[25] and staurosporine can successfully reverse the GC resistance of T lymphoma cells by down-regulating the expression of Bcl-2[24].

In present study, pro-apoptotic Bim and Bad were remarkably up-regulated whereas anti-apoptotic Mcl-1 and Bcl-2 were significantly down-regulated in anisomycin-induced apoptosis of GC-resistant CEM-C1 cells, both of which presented in a concentration- and time-dependent manner (Fig.3). Furthermore, caspase-3, the executioner of both death receptor and mitochondrial pathway of apoptosis, was also activated in anisomycin-triggered apoptosis of CEMC1 cells (Fig.3). These results suggested that anisomycin induced apoptosis in GC-resistant CEM-C1 cells mainly 
A

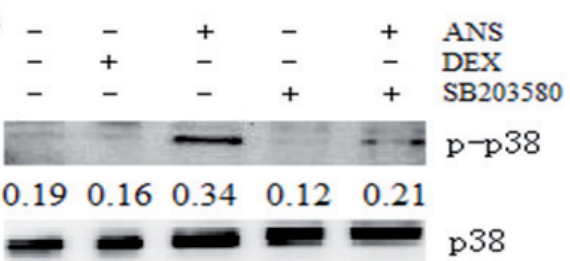

$\begin{array}{lllll}0.34 & 0.33 & 0.39 & 0.38 & 0.41\end{array}$

$\cdots$ BimEL $1 \mathrm{~h}$

$\begin{array}{lllll}0.26 & 0.25 & 0.44 & 0.26 & 0.27\end{array}$

$--\infty M_{\mathrm{cl}-1} \quad 1 \mathrm{~h}$

$\begin{array}{lllll}0.53 & 0.52 & 0.28 & 0.53 & 0.39\end{array}$

$---\mathrm{Bcl}_{-2} 6 \mathrm{~h}$

$\begin{array}{lllll}0.41 & 0.39 & 0.21 & 0.38 & 0.36\end{array}$

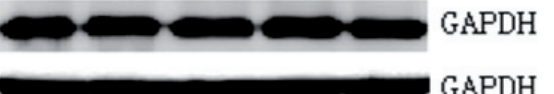

$1 \mathrm{~h}$

$1 \mathrm{~h}$

$1 \mathrm{~h}$

$6 \mathrm{~h}$
B

$\begin{array}{lllllll}- & - & + & - & + & \text { ANS }\end{array}$

$\begin{array}{lllllll}- & + & - & - & - & \mathrm{DEX}\end{array}$

\section{SP600125}

$==_{46 \mathrm{KD}}^{54 \mathrm{KD}} \quad \mathrm{p}-\mathrm{JNK} \quad 30 \mathrm{~min}$

$\begin{array}{lllll}0.07 & 0.07 & 0.73 & 0.06 & 0.07\end{array}$

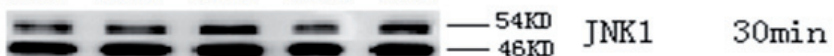

$\begin{array}{llllll}0.72 & 0.75 & 0.77 & 0.70 & 0.74\end{array}$

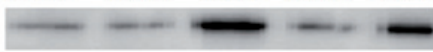

BimEL 1h

$\begin{array}{lllll}0.27 & 0.26 & 0.48 & 0.24 & 0.36\end{array}$

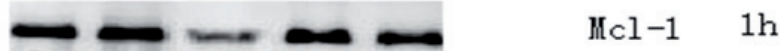

$\begin{array}{lllll}0.50 & 0.52 & 0.31 & 0.50 & 0.49\end{array}$

- - - - $\quad \mathrm{Bcl}-2 \quad 6 \mathrm{~h}$

$\begin{array}{lllll}0.36 & 0.34 & 0.14 & 0.31 & 0.29\end{array}$

GAPDH $30 \mathrm{~min}$

GAPDH $1 \mathrm{~h}$

GAPDH $\quad 6 h$

$\mathrm{C}$

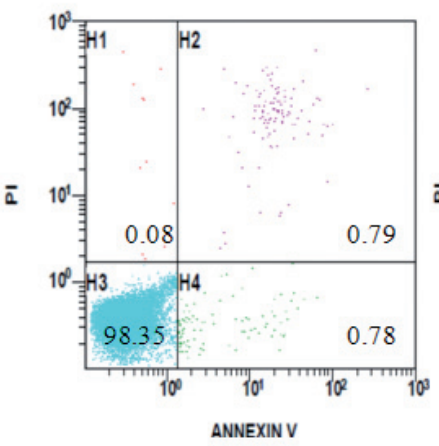

control

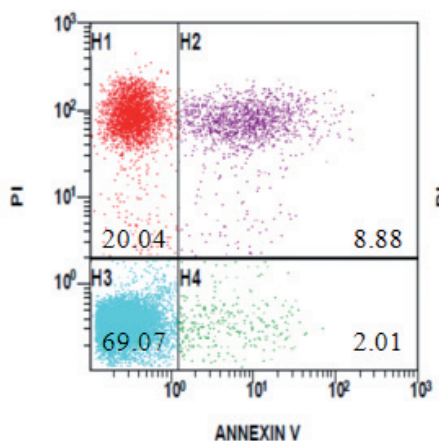

ANS

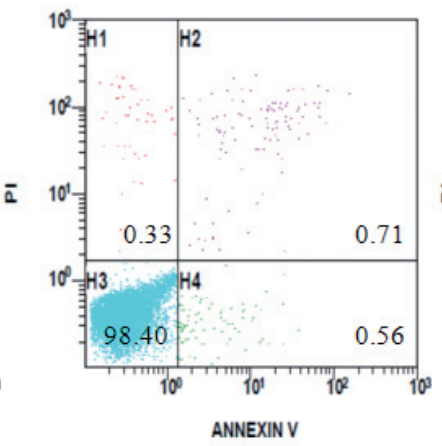

DEX

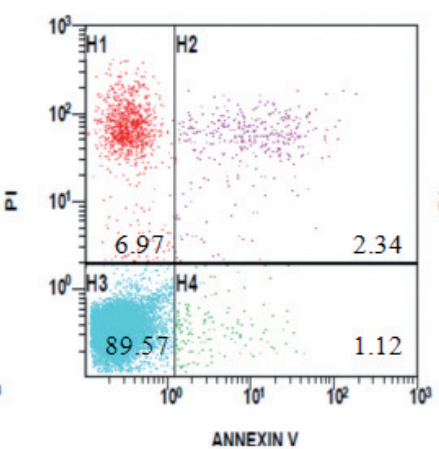

ANS + SB203580

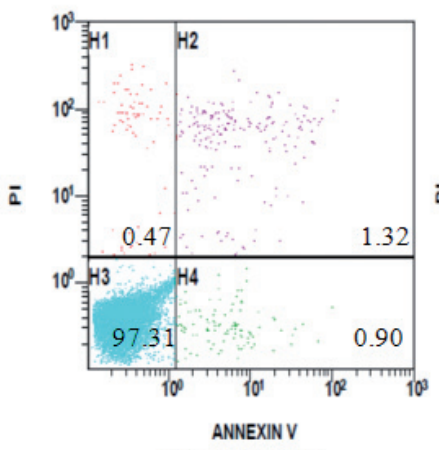

SB203580

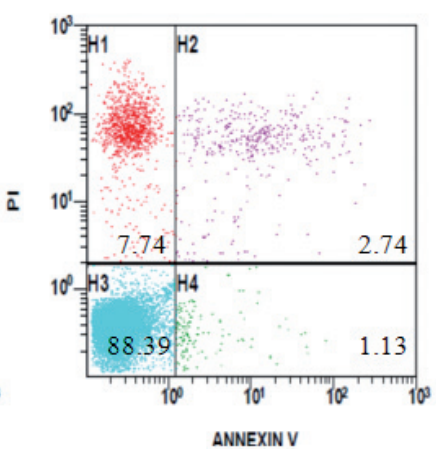

ANS + SP 600125

Figure 7. The anisomycin-induced activation of p38 and JNK in GC-resistant CEM-C1 cells could be blocked by inhibitors of p38(SB203580) and JNK(SP600125). CEM-C1 cells were incubated with no drugs or $1 \mu \mathrm{mol} / \mathrm{L}$ DEX or $1 \mu \mathrm{mol} / \mathrm{L}$ ANS (anisomycin) or inhibitors $(50 \mu \mathrm{mol} / \mathrm{L}$ SB203580 or $50 \mu \mathrm{mol} / \mathrm{L} \mathrm{SP600125)} \mathrm{or} \mathrm{combination} \mathrm{of} 1 \mu \mathrm{mol} / \mathrm{L}$ anisomycin and inhibitors. In the co-treatment groups, cells were preincubated with inhibitors for $1 \mathrm{~h}$ prior to anisomycin treatment. (A) and (B) at the indicated time points, cells were collected, lysed and extracts were subjected to western blot analysis. P-p38 (Thr-180/Tyr-182), p38, p-JNK(Thr-183/Tyr-185), JNK1, BimEL, Mcl-1 and Bcl-2 were detected by using specific antibodies against these proteins. The data of densitometry which standardized by GAPDH are presented below the band. (C) after $24 \mathrm{~h}$ incubation, the percentage of apoptotic cells was determined by Annexin V-FITC/PI staining and flow cytometry. Percentages of each gated fraction (\%) have been marked on the pictures. 
through mitochondria pathway and by regulating capital Bcl-2 family proteins which are tightly associated with GC resistance.

Anisomycin induces cell cycle arrest in CEM-C1 cells through modulating the expression of cell cycle-associated proteins. Proper regulation of cell cycle plays a fundamental role in organisms, as it impacts on cellular division, differentiation and death. In this intricate process, cyclins, together with cyclin-dependent kinases (CDKs) govern cell cycle progression in eukaryotic cells. Progression through the phases of cell cycle relies on cyclin/CDKs complexes that are regulated by multiple cyclin-dependent kinase inhibitors (CKI). CyclinD1 and cyclinA are two important positive agents of cell cycle. CyclinD1 promotes cells to pass G1/S checkpoint and enter $\mathrm{S}$ phase, and cyclin $\mathrm{A}$ is required for DNA replication in S phase. p21 (Cip1) and p27(Kip1) are two important CKIs which negatively regulate cell cycle. p21 interacts with and inhibits various cyclin/CDKs complexes, specifically blocks the initiation of DNA replication and strongly inhibits cyclinA[26]. p27, as a potent tumor-suppressor, can block the phosphorylation of CDKs or directly inhibits the activity of cyclin/CDKs[27]. Previous studies have indicated that cyclinA and cyclinD1 have higher expression while p27(Kip1) has lower expression in childhood and adult leukemia which may contribute to the pathogenesis and the progress of the leukemia[28-30]. In addition, reports also confirmed that the increase of p21 and p27 can inhibit growth of leukemia cells [31].

Although anisomycin can arrest cells at G0/G1 phase [13], the reports about anisomycin regulating cell cycle-related proteins are rare. In present study, anisomycin induced the up-regulation of p21 and p27, and down-regulation of cyclinA in GC-resistant CEM-C1 cells, but it also induced an unexpected up-regulation of cyclinD1. Recent study found that, in addition to promoting cells to pass G1/S checkpoint and enter S phase, cyclinD1 can directly binds RAD51, a recombinase that drives the homologous recombination process in DNA repair induced by radiation, and reduction of cyclinD1 levels in human cancer cells impairs recruitment of RAD51 to damaged DNA, impedes the homologous recombination-mediated DNA repair, and increases sensitivity of cells to radiation in vitro and in vivo[32]. We supposed that anisomycin-induced apoptosis of CEM-C1 cells was companied with DNA damage which might induce the up-regulation of cyclinD1 for DNA repair, but meanwhile decreased cyclinA impeded DNA replication, and additionally up-regulation of p21 and p27 inhibited the activity of cyclinD1. Therefore the integration of anisomycin was to impeded CEM-C1 cells to enter S phase and arrested cells at G1 phase, which was coincident with the results detected by flow cytometry (Fig.4).

JNK and p38-MAPK are involved in anisomycin-induced apoptosis of GC-resistant CEM-C1 cells. Apoptosis of cells is an extremely coordinated phenomenon which involves a series of signaling molecules like stress kinases, caspases and Bcl-2 family proteins[33]. It has been reported that the JNK and p38-MAPK, as two members of MAPK family, are associated with apoptosis of ALL.

The JNK, activated by MAPK cascade, specifically phosphorylates and regulates the activity of transcription factors, nontranscription factors, and also has a central role in regulating many cellular activities from cell cycle progression to apoptosis[34]. JNK has been clouded by controversies because of its role both as an anti-apoptotic and a pro-apoptotic mediator[33]. Treatment of T-ALL cells with JNK inhibitors led to cell cycle arrest and apoptosis, and increased sensitivity to Fas-mediated apoptosis[34]. Activation of the JNK pathway promoted phosphorylation and degradation of BimEL in TALL Sup-T1 cells and conferred resistance of Sup-T1 cells to etoposide-induced apoptosis[35]. However, the apoptosis of P-gp over-expressed T-ALL cells induced by perifosine was in part dependent on the Fas/FasL interaction and JNK activation, and the effect of perifosine-induced down-regulation of P-gp required JNK activity [36]. There were also reports about activation of JNK in anisomycin-induced apoptosis of solid tumor[12].These studies indicate that JNK has promoting or inhibiting apoptotic functions, depending on cell type, nature of the death stimulus, duration of its activation and the activity of other signaling pathways[37].

The p38-MAPK, activated by phosphorylation at tyrosine or serine/threonine sites, participates in the process of apoptosis [38]. Studies have demonstrated that p38-MAPK plays an important role in GC-induced up-regulation of Bim and apoptosis in ALL $[4,15,39]$. Activated p38-MAPK phosphorylates glucocorticoid receptor at serine 211 and triggers cascade of GC-induced apoptosis of ALL[4].

In present study, rapid activation of JNK and p38-MAPK in anisomycin-treated GC-resistant CEM-C1 cells were observed, followed by down-regulation of $\mathrm{Mcl}-1$ and $\mathrm{Bcl}-2$, and up-regulation of BimEL, all of three are important anti- or pro-apoptotic proteins associated with GC resistance in ALL. SP600125 and SB203580, the respective specific inhibitors of JNK and p38-MAPK, could significantly inhibit anisomycininduced activation of JNK and p38-MAPK, also inhibited the anisomycin-induced apoptosis, down-regulation of Mcl-1 and Bcl-2 and up-regulation of Bim, suggesting that JNK and p38-MAPK signaling pathways are critical in anisomycininduced apoptosis of CEM-C1 cells.

In conclusion, our results strongly suggest that anisomycin inhibits GC-resistant CEM-C1 cells growth, induces cell cycle arrest at the G0/G1 phase, and triggers CEM-C1 cells to apoptosis mainly by p38-MAPK and JNK signaling and mitochondrial apoptotic pathway. These results indicate that anisomycin might be a potential drug for treating GC-resistant ALL.

Acknowledgments: This study was supported by grants from the Department of Science and Technology of Sichuan Province, China (No.2008JY0029-1and No.0040215301379) and research funds from program for Changjiang Scholars and Innovative-Research Team in 
University (No.IRT0935). We thank Professor E. Brad Thompson (Department of Human Biological Chemistry and Genetics, university of Texas Medical Branch, Galveston, Texas) for his kindly gifts of ALL-CEM-C1 and CEM-C7 cell lines.

\section{References}

[1] GAYNON PS, CARREL AL. Glucocorticosteroid therapy in childhood acute lymphoblastic leukemia. Adv Exp Med Biol 1999; 457: 593-605. http://dx.doi.org/10.1007/978-1-46154811-9 66

[2] SCHRAPPE M. Evolution of BFM trials for childhood ALL. Ann Hematol 2004; 83(suppl 1): S121-123.

[3] KASPERS GJ, PIETERS R, KLUMPER E, DE WAAL FC, VEERMAN AJ. Glucocorticoid resistance in childhood leukemia. Leuk Lymphoma 1994; 13: 187-201.

[4] MILLER L, WEBB MS, COPIK AJ, WANG Y, JOHNSON BH et al. p38 Mitogen-activated protein kinase (MAPK) is a key mediator in glucocorticoid-induced apoptosis of lymphoid cells: correlation between p38 MAPK activation and site-specific phosphorylation of the human glucocorticoid receptor at serine 211.Mol Endocrinol 2005; 19: 1569-1583. http://dx.doi. org/10.1210/me.2004-0528

[5] TANAKA T, OKABE T, GONDO S, FUKUDA M, YAMAMOTO M, et al. Modification of glucocorticoid sensitivity by MAP kinase signaling pathways in glucocorticoid-induced T-cell apoptosis. Exp Hematol 2006; 34: 1542-1552. http://dx.doi. org/10.1016/j.exphem.2006.06.018

[6] BARROS LF, YOUNG M, SAKLATVALA J, BALDWIN SA. Evidence of two mechanisms for the activation of the glucose transporter GLUT1 by anisomycin: p38(MAP kinase) activation and protein synthesis inhibition in mammalian cells. J Physiol 1997; 1; 504: 517-525.

[7] YANG H, CHOI HJ, PARK SH, KIM JS, MOON Y. Macrophage inhibitory cytokine-1 (MIC-1) and subsequent urokinase-type plasminogen activator mediate cell death responses by ribotoxic anisomycin in HCT-116 colon cancer cells. Biochem Pharmacol 2009; 78: 1205-1213. http://dx.doi. org/10.1016/j.bcp.2009.06.012

[8] ABAYASIRIWARDANA KS, BARBONE D, KIM KU, VIVO C, LEE KK, et al. Malignant mesothelioma cells are rapidly sensitized to TRAIL-induced apoptosis by low-dose anisomycin via Bim. Mol Cancer Ther 2007; 6: 2766-2776. http://dx.doi. org/10.1158/1535-7163.MCT-07-0278

[9] PAP M, SZEBERENYI J. Involvement of proteolytic activation of protein kinase R in the apoptosis of PC12 pheochromocytoma cells. Cell Mol Neurobiol 2008; 28: 443-456. http://dx.doi. org/10.1007/s10571-007-9245-y

[10] XIA S, LI Y, ROSEN EM, LATERRA J. Ribotoxic stress sensitizes glioblastoma cells to death receptor induced apoptosis: requirements for c-Jun NH2-Terminal Kinase and Bim. Mol Cancer Res 2007; 5: 783-792. http://dx.doi.org/10.1158/15417786.MCR-06-0433

[11] MIZUNO R, OYA M, SHIOMI T, MARUMO K, OKADA Y, et al. Inhibition of MKP-1 expression potentiates JNK related apoptosis in renal cancer cells. J Urol 2004; 172: 723-727. http://dx.doi.org/10.1097/01.ju.0000124990.37563.00
[12] CURTIN JF, COTTER TG. Anisomycin activates JNK and sensitizes DU145 prostate carcinoma cells to Fas mediated apoptosis. Br J Cancer 2002; 87: 1188-1194. http://dx.doi. org/10.1038/sj.bjc. 6600612

[13] HORI T, KONDO T, TABUCHI Y, TAKASAKI I, ZHAO QL, et al. Molecular mechanism of apoptosis and gene expressions in human lymphoma U937 cells treated with anisomycin. Chem Biol Interact 2008; 172: 125-140. http://dx.doi.org/10.1016/ j.cbi.2007.12.003

[14] ZAWYDIWSKI R, HARMON JM, THOMPSON EB. Glucocorticoid-resistant human acute lymphoblastic leukemic cell line with functional receptor. Cancer Res 1983; 43: 3865-3873.

[15] ZHAO YN, GUO X, MA ZG, GU L, GE J, et al. Pro-apoptotic protein BIM in apoptosis of glucocorticoid-sensitive and -resistant acute lymphoblastic leukemia CEM cells. Med Oncol 2011; 28: 1609-1617. http://dx.doi.org/10.1007/s12032-0109641-X

[16] STAM RW, DEN BOER ML, SCHNEIDER P, DE BOER J, HAGELSTEIN J, et al. Association of high-level MCL-1 expression with in vitro and in vivo prednisone resistance in MLL-rearranged infant acute lymphoblastic leukemia. Blood 2010; 115: 1018-1025. http://dx.doi.org/10.1182/blood-200902-205963

[17] JIANG N, KOH GS, LIM JY, KHAM SK, ARIFFIN H, et al. BIM is a prognostic biomarker for early prednisolone response in pediatric acute lymphoblastic leukemia. Exp Hematol 2011; 39: 321-329. http://dx.doi.org/10.1016/ j.exphem.2010.11.009

[18] WANG Z, MALONE MH, HH H, MCCOLL KS, DISTELHORST CW. Microarray analysis uncovers the induction of the proapoptotic $\mathrm{BH} 3$-only protein BIM in multiple models of glucocorticoid induced apoptosis. J Biol Chem 2003; 278: 23861-23867. http://dx.doi.org/10.1074/jbc.M301843200

[19] ABRAMS MT, ROBERTSON NM, YOON K, WICKSTROM E. Inhibition of Glucocorticoid-induced apoptosis by targeting the major splice variants of BIM mRNA with small interfering RNA and short hairpin RNA. J Biol Chem 2004; 279: 55809-55817. http://dx.doi.org/10.1074/jbc. M411767200

[20] MERINO D, STRASSER A, BOUILLET P. Bim must be able to engage all pro-survival Bcl-2 family members for efficient tumor suppression. Oncogene 2011; doi: 10.1038/onc.2011.508. http://dx.doi.org/10.1038/onc.2011.508

[21] GHIOTTO F, FAIS F, BRUNO S. BH3-only proteins: the death-puppeteer's wires. Cytometry A 2010; 77: 11-21.

[22] QUINN BA, DASH R, AZAB B, SARKAR S, DAS SK, et al. Targeting Mcl-1 for the therapy of cancer. Expert Opin Investig Drugs 2011; 20: 1397-1411. http://dx.doi. org/10.1517/13543784.2011.609167

[23] STAVROVSKAYA AA. Cellular mechanisms of multidrug resistance of tumor cells. Biochemistry (Mosc) 2000; 65: 95-106. [24] Kfir S, SIONOV RV, ZAFRIR E, ZILBERMAN Y, YEFENOF E. Staurosporine sensitizes T lymphoma cells to glucocorticoid-induced apoptosis: role of Nur77 and Bcl-2. Cell Cycle 2007; 6: 3086-3096. http://dx.doi.org/10.4161/ cc.6.24.5023 
[25] PEPPER C, HOY T, BENTLEY P. Elevated Bcl-2/Bax are a consistent feature of apoptosis resistance in B-cell chronic lymphocytic leukaemia and are correlated with in vivo chemoresistance. Leuk Lymphoma 1998; 28: 355-361.

[26] STRAUSFELD UP, HOWELL M, REMPEL R, MALLER JL, HUNT T, et al . Cip1 blocks the initiation of DNA replication in Xenopus extracts by inhibition of cyclin-dependent kinases. Curr Biol 1994; 4: 876-883. http://dx.doi.org/10.1016/S09609822(00)00196-2

[27] SGAMBATO A, CITTADINI A, FARAGLIA B, WEINSTEIN IB. Multiple functions of p27 (Kip1) and its alterations in tumor cells: a review. J Cell Physiol 2000; 183: 18-27. http:// dx.doi.org/10.1002/(SICI)1097-4652(200004)183:1<18::AIDLCP3>3.0.CO; $2-\mathrm{S}$

[28] HIRT A, SCHMID AM, JULMY F, SCHMITZ NM, LEIBUNDGUT K. Expression of cyclin A in childhood acute lymphoblastic leukemia cells reveals undisturbed G1-S phase transition and passage through the $S$ phase. Leukemia 2009; 23: 414-417. http://dx.doi.org/10.1038/leu.2008.200

[29] AREF S, MABED M, EL-SHERBINY M, SELIM T, METWALY A. Cyclin D1 expression in acute leukemia. Hematology 2006; 11: 31-34. http://dx.doi.org/10.1080/10245330500322321

[30] WU SJ, DU X, CHEN YX, JIANG WL, ZHONG LY, et al. Relationship between cyclins and prognosis of acute leukemia. Ai Zheng 2003; 22: 852-855.

[31] YUAN C, ZHANG YS, CHENG YN, XUE X, XU WF, et al. A112, a tamibarotene dimethylaminoethyl ester, may inhibit human leukemia cell growth more potently than tamibarotene. Leuk Lymphoma 2012; 53: 295-304. http://dx.doi. org/10.3109/10428194.2011.614707

[32] JIRAWATNOTAI S, HU Y, MICHOWSKI W, ELIAS JE, BECKS L, et al. A function for cyclin D1 in DNA repair uncovered by protein interactome analyses in human cancers.
Nature 2011; 474: 230-234. http://dx.doi.org/10.1038/ nature 10155

[33] VERMA G, DATTA M. The critical role of JNK in the ER-mitochondrial crosstalk during apoptotic cell death. J Cell Physiol 2012; 227: 1791-1795. http://dx.doi.org/10.1002/jcp.22903

[34] CUI J, WANG Q, WANG J, LV M, ZHU N, et al. Basal c-Jun $\mathrm{NH} 2$-terminal protein kinase activity is essential for survival and proliferation of T-cell acute lymphoblastic leukemia cells. Mol Cancer Ther 2009; 8: 3214-3222. http://dx.doi. org/10.1158/1535-7163.MCT-09-0408

[35] LEUNG KT, LI KK, SUN SS, CHAN PK, OOI VE, et al. Activation of the JNK pathway promotes phosphorylation and degradation of BimEL--a novel mechanism of chemoresistance in T-cell acute lymphoblastic leukemia. Carcinogenesis 2008; 29: 544-551.

[36] CHIARINI F, DEL SOLE M, MONGIORGI S, GABOARDI GC, CAPPELLINI A, et al. The novel Akt inhibitor, perifosine, induces caspase-dependent apoptosis and downregulates Pglycoprotein expression in multidrug-resistant human T-acute leukemia cells by a JNK-dependent mechanism. Leukemia 2008; 22: 1106-1116. http://dx.doi.org/10.1038/leu.2008.79

[37] LIU J, LIN A. Role of JNK activation in apoptosis: a double-edged sword. Cell Res 2005; 15: 36-42. http://dx.doi. org/10.1038/sj.cr.7290262

[38] ENSLEN H, BRANCHO DM, DAVIS RJ. Molecular determinants that mediate selective activation of p38 MAP kinase isoforms. EMBO J 2000; 19: 1301-1311. http://dx.doi. org/10.1093/emboj/19.6.1301

[39] LU J, QUEARRY B, HARADA H. p38-MAP kinase activation followed by BIM induction is essential for glucocorticoidinduced apoptosis in lymphoblastic leukemia cells. FEBS Lett 2006; 580: 3539-3544. http://dx.doi.org/10.1016/ j.febslet.2006.05.031 